\title{
2 Dental casting alloys behaviour during power toothbrushing 3 with toothpastes with various abrasivities. Part I: wear behavior
}

\author{
4 Ll. Nogués · J. Martinez-Gomis · C. Molina • M. Peraire • \\ 5 J. Salsench $\cdot$ P. Sevilla $\cdot$ F. J. Gil
}

8 Abstract The purpose of this study was to evaluate the 9 long term effect of abrasivity of toothpastes normally used 10 over the surface and mechanical properties of dental casting 11 alloys. Three dental casting alloys ( $\mathrm{Ni}-\mathrm{Cr}, \mathrm{Co}-\mathrm{Cr}$, c.p. Ti) 12 and one ceramic were chosen. Four specimens of each 13 material were immersed in artificial saliva, brushed without 14 or with one of four toothpastes of different Relative Dentine 15 Abrasivity (RDA 50, 52, 80, and 114). An electric tooth16 brush with a load of $250 \mathrm{~g}$ was used for $420 \mathrm{~min}$. Mass loss 17 was determined by difference in weight, microhardness and 18 surface roughness were also measured. Two-way ANOVA 19 and non-parametric tests were used to detect significant 20 differences. Titanium specimens $\left(478 \mu \mathrm{g} / \mathrm{cm}^{2}\right)$ exhibited 21 the most mass loss, whereas ceramic $\left(282 \mu \mathrm{g} / \mathrm{cm}^{2}\right)$ and $22 \mathrm{Co}-\mathrm{Cr}\left(262 \mu \mathrm{g} / \mathrm{cm}^{2}\right)$ exhibited the least. However, ceramic 23 demonstrated the most volume loss $\left(0.239 \mathrm{~mm}^{3}\right)$. The 24 abrasivity effect of the toothpaste correlated with the RDA 25 values. Slight variations in microhardness were observed 26 after toothbrushing and depended on the material but not on 27 the toothpaste used. Material surfaces were slightly 28 smoothed by toothbrushing but no significant differences
Ll. Nogués · J. Martinez-Gomis · C. Molina - M. Peraire · J. Salsench · F. J. Gil

Department of Prosthodontics, Faculty of Dentistry,

Universitat de Barcelona, Barcelona, Spain

\section{P. Sevilla}

Catalonia Bioengineering Institute (IBEC), Department of Materials Science and Metallurgical Engineering, Universitat Politècnica de Catalunya, Barcelona, Spain

\section{F. J. Gil (ه)}

Department of Materials Science and Metallurgical Engineering, ETSEIB, Universitat Politècnica de Catalunya, Av.Diagonal 647, 08028 Barcelona, Spain

e-mail: francesc.xavier.gil@upc.edu were detected. Dental casting alloys and ceramic are susceptible to abrasion by brushing with an electric toothbrush depending on the RDA value of the toothpaste. Variations in microhardness and surface roughness were not clinically relevant.

\section{Introduction}

Brushing with toothpaste is the most common form of tooth cleaning. Although manual toothbrushes are still used by the majority of people, powered toothbrushes are becoming increasingly popular [1]. In a comparative study of three power toothbrush systems the authors concluded that the action of the oscillating/rotating/pulsating toothbrushes was more effective in plaque removal than the high-frequency toothbrush [2]. Moreover, a systematic review of the literature concluded that powered toothbrushes with a rotation oscillation action achieve a modest reduction in plaque and gingivitis compared to manual toothbrushing. However, few data have been reported concerning the side effects of their use [1]. To achieve optimum toothbrushing, it is necessary to add organic solvents and abrasive substances to the toothpaste. The abrasivity of such substances should never be so high that unintended damage is produced in the oral hard or soft tissues, or in dental restorations. Abrasion induced by an abrasive agent on a surface is influenced by a great variety of the agent's properties, such as chemical composition, crystal structure, cleavage, friability, hardness, particle shape, surface features, and particle size distribution, solubility, concentration, and compatibility with other ingredients of the toothpaste. The abrasivity of toothpastes can be measured by a variety of methods in vitro, of which 
62 the Relative Dentine Abrasion (RDA) method [3] is the 63 best known, recommended by the International Standards 64 Organization [4].

Abrasion from brushing has been studied on enamel [5, 6], dentin [5, 7, 8] composite [9] acrylic resin [8, 10-12], ceramic [13], glass ionomer [14] and amalgam [14]. However, only a few in vitro studies have focused on the effects of brushing on dental alloys [15-17]. Whereas Ni-based (Ni-Cr and $\mathrm{Ni}-\mathrm{Cr}-\mathrm{Be}$ ) alloys showed relatively high amounts $\left(600-800 \mu \mathrm{g} / \mathrm{cm}^{2}\right.$ of $\left.\mathrm{Ni}\right)$ of elemental release after brushing with toothpaste for $48 \mathrm{~h}$ [16], only $\mathrm{Ni}-\mathrm{Cr}-\mathrm{Be}$ alloy showed a large increase in cytotoxicity under the same conditions [17].

There are currently hundreds of alloys available for prosthodontic restorations. The major factors controlling alloy selection are cost, physical properties, casting techniques, corrosion and biocompatibility [18-21]. For clinical dental applications, $\mathrm{Ni}-\mathrm{Cr}$ and $\mathrm{Co}-\mathrm{Cr}$ alloys have been developed as a cheaper alternative to gold-and palladium-based alloys, also featuring mechanical properties $[20,21]$. Titanium is a relatively new metal in cast dental prostheses [22]. Whereas titanium has several advantages compared to $\mathrm{Ni}-\mathrm{Cr}$ and $\mathrm{Co}-\mathrm{Cr}$, including lower weight, biocompatibility and low heat conductivity, it also suffers from a complex casting technique, requiring high temperature $\left(1650^{\circ} \mathrm{C}\right)$, a special magnesium investment, and an argon arc under vacuum [20, 22].

Brushing with toothpaste may lead to changes in the surface morphology of both natural tooth and restorative materials. These changes may alter plaque retention and corrosion potential. The aim of this study was to evaluate the long term effect of abrasivity of toothpastes normally used over the surface and the mechanical properties of $\mathrm{Ni}-\mathrm{Cr}, \mathrm{Co}-\mathrm{Cr}$, and commercially pure titanium (cpTi) after power toothbrushing. In order to achieve it an in vitro study was developed using rotating oscillation toothbrushes and different toothpastes in artificial saliva.

\section{Materials and methods}

Three types of casting alloys used for full cast and porcelain-fused-to-metal restorations were selected. These were Ni-Cr alloy (IPS d.SIGN 15, Ivoclar Vivadent AG, Schaan, Liechtenstein) (composition \% by weight; Ni:58.7, Cr:12.1, $\mathrm{Si}: 1.9, \mathrm{Mo}: 1.7, \mathrm{Fe}:<1, \mathrm{Co}:<1, \mathrm{Ce}:<1$ ), Co-Cr alloy (IPS d.SIGN 30, Ivoclar Vivadent Inc, Amherst, NY, USA) (composition \% by weight; Co:60.2, Cr:30.1\%, Ga:3.9, $\mathrm{Nb}: 3.2, \mathrm{~B}:<0.1, \mathrm{Fe}:<0.1, \mathrm{Al}:<0.1, \mathrm{Li}:<0.1)$ and cpTi grade II (Tritan ${ }^{\circledR}$, Dentaurum, Ispringen, Germany) (Composition $\%$ by weight; Ti: $>99.5 \%$ ). One ceramic material (Vintage Halo Porcelain, Shofu, San Marcos, CA, USA) was chosen as a control because of its abrasion resistance. 120 wax patterns $(18 \times 18 \mathrm{~mm}$ and $1.5 \mathrm{~mm}$ thick $)$ were cast. Eighty of them were invested in phosphate-bonded investment (Ceramvest, Protechno, Vilamalla, Spain) to obtain 40 specimens of $\mathrm{Ni}-\mathrm{Cr}$ and 40 of $\mathrm{Co}-\mathrm{Cr}$. For the remaining 40 wax patterns, a magnesia-based investment material (Trinell ${ }^{\circledR}$, Dentaurum, Ispringen, Germany) was used to obtain the cpTi specimens by means of an appropriate casting machine (Rematitan Autocast, Dentaurum, Ispringen, Germany). Investment heating and alloy casting procedures were performed according to the manufacture's instructions. All alloys were fired at $950^{\circ} \mathrm{C}$ to simulate firing in a porcelain oven. Forty specimens of porcelain were produced by means of a mold $(18 \times 18 \mathrm{~mm}$ and $1.5 \mathrm{~mm}$ thick) and fired in a high-temperature porcelain oven. After casting, the alloy specimens and the porcelain were polished following standard laboratory procedures and then cleaned.

Before brushing, all specimens were weighed and their surface roughness was measured using a profilometer as described later. Forty specimens of each restorative material were randomly distributed amongst five groups $(n=8)$. Four specimens from each group were brushed either without paste or with one of the following four commercial toothpastes: (0) artificial saliva (Hank's Balanced Salt Solution, Sigma-Aldrich, UK) without toothpaste as a control, (1) Paste-50 (Sorbitol, aqua, hydrated silica, PEG-12, aroma, tetrasodium pyrophosphate, cellulose gum, sodium lauryl sulfate, sodium saccharin, sodium fluoride, mica, glycerin, CI 42090, CI 77891, RDA $=50$ ), (2) Paste-52 (sodium fluoride, dihydrated dicalcium phosphate, glycerin, aqua, alumina, sorbitol, sodium citrate, cocamidopropyl betaine, papaine, sodium lauryl sulfate, carrageenan, sodium sacharin, CI 42090, citroxain $^{\circledR}$, RDA $=52$ ), (3) Paste-80 (Aqua, hydrated silica, glicerin, sorbitol, PVM/MA copolymer, sodium lauryl sulfate, aroma, cellulose gum, sodium hydroxide, sodium fluoride, triclosan, carrageenan, sodium sacharin, CI 77891, RDA = 80), and (4) Paste-114 (Aqua, hydrated silica, sorbitol, glycerin, PEG-12, tetrapotassium pyrophosphate, PVM/MA copolymer, aroma, sodium lauryl sulfate, titanium dioxide, cellulose gum, carrageenan, sodium fluoride, sodium hydroxide, sodium saccharin, RDA = 114). The authors chose these toothpastes as they are widely used and represent a wide range of RDA values. The four remaining specimens from each group were merely immersed in toothpaste or artificial saliva without any brushing.

An electric toothbrush (Braun Oral-B ProfessionalCare 7500DLX, Braun AG, Kronberg, Germany) was chosen because it is one of recent models of power toothbrushes which has a pulsating action added to an oscillating/rotating action, and in order to realistically imitate real brushing of the restorative materials. This electric toothbrush effects 
an in-and-out movement at 40000 pulsations per minute, with simultaneous oscillations at 8800 per minute. The brush heads used were Green Oral-B ${ }^{\circledR}$ (FlexiSoft ${ }^{\circledR}$ bristles). Batteries from each of four units of this electric toothbrush were removed and a power supply with direct current was connected to obtain a voltage of $5 \mathrm{~V}$. Since brushing engines need $1.2 \mathrm{~V}$ to work, a bridge of five diodes was installed at the power supply output and the four electric toothbrushes were connected in parallel just beyond the diode bridge (Fig. 1).

Specimens were fixed into a round-shaped plastic recipient and were totally immersed in abrasive slurry containing

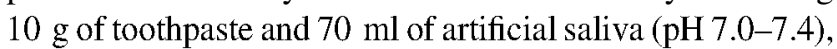
except for the group without toothpaste which was immersed only in artificial saliva. For the specimens to be brushed, a weight was added to the base upon which each electric toothbrush was fixed in order to give the specimen a vertical load of $250 \mathrm{~g}( \pm 3 \mathrm{~g})$ during brushing. Each experiment was allowed to run for $7 \mathrm{~h}$ at room temperature $\left(20 \pm 3^{\circ} \mathrm{C}\right)$. A new toothbrush and fresh slurry was used for each specimen.

After brushing, each sample was rinsed with distilled water and air dried for $10 \mathrm{~s}$. Specimens were weighed using an electronic balance (Sartorius BP211D, Sartorius AG, Goettingen, Germany, accuracy of $0.01 \mathrm{mg}$ ) at the beginning of the experiment and after 70, 140, 280 and $420 \mathrm{~min}$ of brushing/immersion. The area of brushing was calculated soaking the bristles of a toothbrush with ink under the experimental situation by means of an image analyzer and the result was $1.936 \mathrm{~cm}^{2}$. The material loss per unit area was determined by dividing the difference in weight before and after brushing/immersion by $1.936 \mathrm{~cm}^{2}$ at each time. The volume loss was calculated as the weight loss divided by the density of each material.

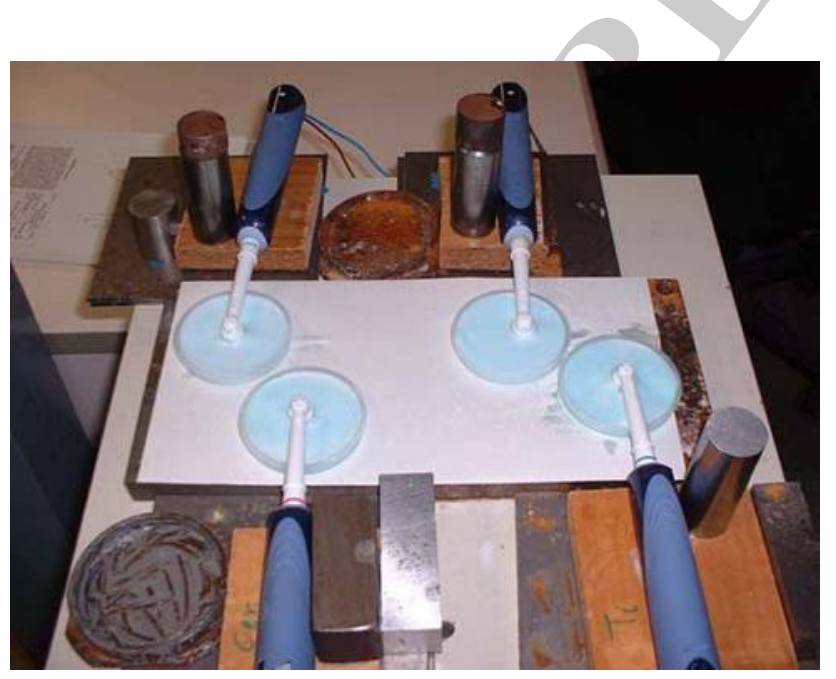

Fig. 1 The materials tested immersed in toothpaste slurry and placed into four plastic recipients are submitted to brushing by four units of electric toothbrush which are fixed to platforms subjected to a $250 \mathrm{~g}$ load
The surface roughness measurements were made using a profilometer (Mitutoyo Surftest SV-512; Mitutoyo, IL, USA) with a $5 \mathrm{~nm}$ resolution and assisted with appropriate software (Surfpack, v 3.0, Mitutoyo, Japan) on the specimens before and after $420 \mathrm{~min}$ of brushing. Before evaluation, a Gaussian filter was used to remove errors of form and waviness. For each specimen five different lengths (sampling length $0.8 \mathrm{~mm}$, and transversing length $2.5 \mathrm{~mm}$ ) were analyzed following the ISO/JIS B0601. Ra was used to give a numerical characterization of the surface roughness. $\mathrm{Ra}$ is the arithmetical mean deviation of the profile and is calculated as the arithmetical mean of the absolute values of the profile deviations from the mean line. One centrally positioned surface area was analyzed and care was taken to relocate the same area during subsequent registrations. The microhardness of the materials was measured using a microhardness tester (Matsuzawa DMH1) at a load of $500 \mathrm{~g}$ for $15 \mathrm{~s}$, before brushing and after $420 \mathrm{~min}$ of brushing. Five different areas for each specimen were chosen to make indentations and were averaged. Care was taken to ensure that testing was performed on a flat surface.

Specimens of each material were examined in a scanning electron microscope (SEM) (JEOL ${ }^{\circledR} \mathrm{JSM}-6400$, Jeol USA Inc, Peabody, Ma, USA) before and after brushing with different toothpastes, at a constant working distance of $10 \mathrm{~mm}$, with magnifications $500 \times, 1000 \times$, or $2000 \times$. Ceramic specimens were gold-sputtered (Balzers SCD 004, USA) for $40 \mathrm{~s}$ with a $10 \mathrm{~nm}$ layer and then viewed under vacuum in a SEM. Alloy specimens were not coated with any material due to their metallic nature. Toothpastes were examined by means of environmental scanning electron microscopy (ESEM) (JEOL 2020 electroscan $^{\circledR}$, Jeol USA Inc, Peabody, Ma, USA) with magnifications of up to $1000 \times$.

Statistical analyses was performed using SPSS $12.0 \mathrm{~S}$ for Windows (SPSS Inc, Chicago, IL, USA). Two-way ANOVA and post hoc Tukey tests were used to examine the effects of toothpaste and restorative material, as well as any interaction effects, on mass loss and microhardness. The amount of variation explained by the model was determined by the adjusted $R^{2}$ values. Volume loss and surface roughness data were analyzed using the Mann-Whitney $U$ and Wilcoxon signed-rank tests. Statistical significance was set in advance at the 0.05 probability level.

\section{Results}

None of the specimens that were simply immersed in toothpaste, without brushing, exhibited mass loss. Mass loss curves for materials brushed are shown in Fig. 2. The rate of mass loss decreased as a function of time. Mass loss per unit area values for all materials and for all toothpastes after $420 \mathrm{~min}$ of brushing are given in Table 1. A two-way 


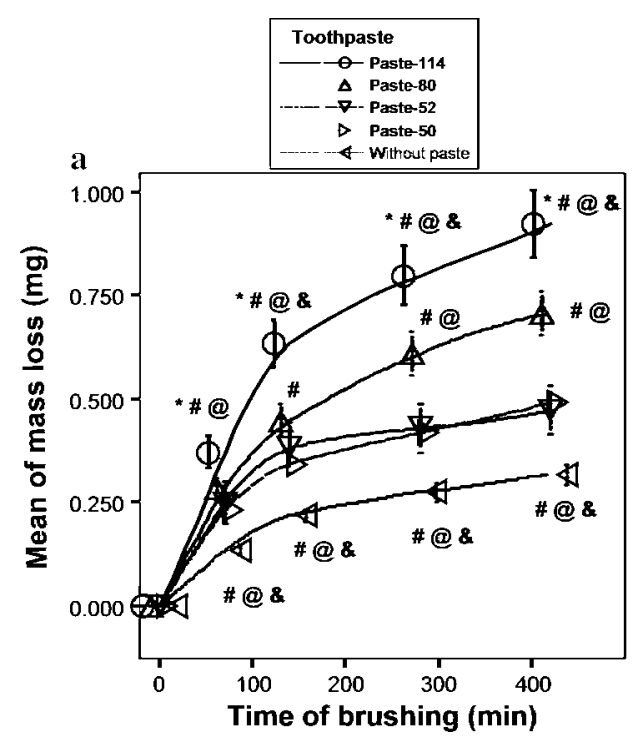

Fig. 2 (a) Mean of mass loss (mg) of the four materials tested produced by brushing without toothpaste and with the four different toothpastes over $420 \mathrm{~min}$. (b) Mean of mass loss (mg) for each material tested produced by brushing over $420 \mathrm{~min}$ regardless of the toothpaste used. Error bars represent Standard Error of Means. Statistical
ANOVA revealed that both material and the type of toothpaste had significant effects on mass loss $\left(R_{\mathrm{a}}^{2}=0.85\right.$; $P<0.001)$. Titanium suffered the most abrasion whereas $\mathrm{Co}-\mathrm{Cr}$ and ceramic suffered the least. Further, the higher the RDA of the toothpaste produced the higher the mass loss in the materials tested. The ANOVA also revealed a significant interaction between toothpaste and material $(P<0.001)$. Whereas abrasion of titanium, Ni-Cr and ceramic depended significantly on the RDA of the toothpaste used, $\mathrm{Co}-\mathrm{Cr}$ exhibited a similar mass loss for all the

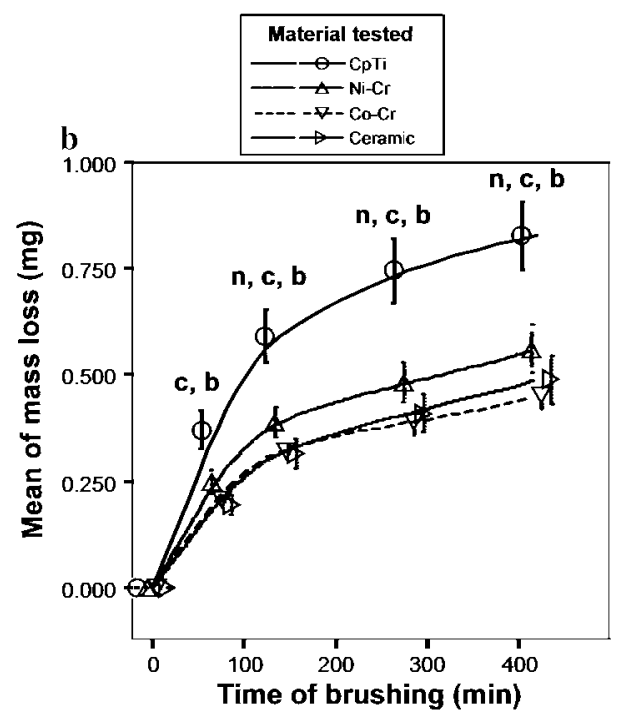

significant differences are indicated by: $* P<0.05$ with respect to "without paste"; ${ }^{\#} P<0.05$ with respect to Paste-50; ${ }^{\circledR} P<0.05$ with respect to Paste-52; ${ }^{\&} P<0.05$ with respect to Paste- $80 ;{ }^{\mathrm{c}} P<0.05$ with respect to ceramic; ${ }^{\mathrm{b}} P<0.05$ with respect to $\mathrm{Co}-\mathrm{Cr}$; ${ }^{\mathrm{n}} P<0.05$ with respect to Ni-Cr. Analyzed by Mann-Whitney $U$ test

toothpastes tests. In contrast, Mann-Whitney $U$ and Wilcoxon signed-rank tests revealed that ceramic lost more volume $(P<0.001)$ that $\mathrm{Co}-\mathrm{Cr}$ or $\mathrm{Ni}-\mathrm{Cr}$ after $420 \mathrm{~min}$ of brushing (Table 2).

A slight but no significant variation in surface roughness was observed after brushing with or without toothpaste for all restorative materials (Table 3 ). Vickers hardness values are presented in Table 4. The hardness of $\mathrm{Ni}-\mathrm{Cr}$ alloy is significantly $(P<0.01)$ lower than that of the other materials tested, whilst $\mathrm{Co}-\mathrm{Cr}$ exhibited the highest

Table 1 Means (SD) of mass per unit area $\left(\mu \mathrm{g} / \mathrm{cm}^{2}\right)$ after $420 \mathrm{~min}$ as a result of brushing with or without toothpaste for each restorative material

\begin{tabular}{lllllll}
\hline & Without paste & Paste-50 Silica & Paste-52 alumina & Paste-80 Silica & Paste-114 Silica $+\mathrm{TiO}_{2}$ & Mean toothpaste* $^{*}$ \\
\hline Ceramic & $136(21)$ & $213(37)$ & $136(62)$ & $359(36)$ & $418(75)$ & $282(126)^{\mathrm{x}, \mathrm{y}}$ \\
$\mathrm{Co}-\mathrm{Cr}$ & $112(14)$ & $245(58)$ & $269(83)$ & $252(41)$ & $284(32)$ & $262(53)^{\mathrm{x}}$ \\
$\mathrm{Ni}-\mathrm{Cr}$ & $186(18)$ & $241(51)$ & $191(89)$ & $332(42)$ & $498(37)$ & $316(132)^{\mathrm{y}}$ \\
$\mathrm{cpTi}$ & $223(38)$ & $314(75)$ & $381(114)$ & $516(65)$ & $702(69)$ & $478(170)^{\mathrm{z}}$ \\
Mean & $164(50)^{\mathrm{a}}$ & $253(64)^{\mathrm{b}}$ & $244(124)^{\mathrm{b}}$ & $365(108)^{\mathrm{c}}$ & $476(165)^{\mathrm{d}}$ & \\
\hline
\end{tabular}

* Mean for 4 types of toothpaste. Different letters indicate statistical differences (two-way ANOVA, Tukey post-hoc test, $P<0.05$ )

Table 2 Means (SD) of volume loss $\left(\mathrm{mm}^{3}\right)$ after $420 \mathrm{~min}$ as a result of brushing with or without toothpaste for each restorative material

\begin{tabular}{lllllll}
\hline & Without paste & Paste-50 Silica & Paste-52 alumina & Paste-80 Silica & Paste-114 Silica $+\mathrm{TiO}_{2}$ & MEAN toothpaste $^{*}$ \\
\hline Ceramic & $0.115(0.017)$ & $0.181(0.032)$ & $0.115(0.052)$ & $0.305(0.031)$ & $0.355(0.064)$ & $0.239(0.107)^{\mathrm{x}}$ \\
$\mathrm{Co}-\mathrm{Cr}$ & $0.027(0.003)$ & $0.058(0.014)$ & $0.063(0.020)$ & $0.059(0.010)$ & $0.067(0.008)$ & $0.062(0.013)^{\mathrm{y}}$ \\
$\mathrm{Ni}-\mathrm{Cr}$ & $0.045(0.004)$ & $0.058(0.012)$ & $0.046(0.021)$ & $0.080(0.010)$ & $0.120(0.009)$ & $0.076(0.032)^{\mathrm{y}}$ \\
cpTi & $0.096(0.016)$ & $0.135(0.032)$ & $0.164(0.049)$ & $0.221(0.028)$ & $0.221(0.028)$ & $0.205(0.073)^{\mathrm{x}}$ \\
Mean material & $0.071(0.039)^{\mathrm{a}}$ & $0.108(0.058)^{\mathrm{b}}$ & $0.0166(0.059)^{\mathrm{a}, \mathrm{b}, \mathrm{c}}$ & $0.166(0.108)^{\mathrm{b}, \mathrm{c}, \mathrm{d}}$ & $0.211(0.128)^{\mathrm{d}}$ &
\end{tabular}

* Mean for 4 types of toothpaste. Different letters indicate statistical differences (Mann-Withney $U$ and Wilcoxon signed-rank tests, $P<0.05$ ) 
Table 3 Means (SD) of initial surface roughness $\left(\mathrm{R}_{\mathrm{a}}\right)$ and change of $\mathrm{R}_{\mathrm{a}}$ after brushing

\begin{tabular}{|c|c|c|c|c|c|c|c|}
\hline & $\begin{array}{l}\text { Before } \\
\text { brushing }\end{array}$ & $\begin{array}{l}\text { Without } \\
\text { paste }\end{array}$ & $\begin{array}{l}\text { Paste-50 } \\
\text { Silica }\end{array}$ & $\begin{array}{l}\text { Paste-52 } \\
\text { alumina }\end{array}$ & $\begin{array}{l}\text { Paste-80 } \\
\text { Silica }\end{array}$ & $\begin{array}{l}\text { Paste- } 114 \\
\text { Silica }+\mathrm{TiO}_{2}\end{array}$ & $\begin{array}{l}\text { MEAN } \\
\text { toothpaste }\end{array}$ \\
\hline Ceramic & $0.64(0.10)$ & -0.09 & 0 & -0.15 & -0.09 & -0.14 & -0.09 \\
\hline $\mathrm{Co}-\mathrm{Cr}$ & $0.52(0.09)$ & -0.05 & 0 & -0.05 & -0.13 & -0.09 & -0.07 \\
\hline $\mathrm{Ni}-\mathrm{Cr}$ & $0.73(0.09)$ & -0.05 & -0.12 & -0.06 & -0.01 & -0.02 & -0.05 \\
\hline cpTi & $0.41(0.07)$ & -0.03 & +0.16 & -0.06 & +0.15 & -0.15 & +0.03 \\
\hline \multicolumn{2}{|c|}{ Mean material } & -0.06 & +0.01 & -0.08 & -0.02 & -0.10 & \\
\hline
\end{tabular}

Table 4 Means (SD) of initial Vickers hardness (HVN) and change in VHN after 420 min of brushing with or without toothpaste

\begin{tabular}{|c|c|c|c|c|c|c|c|}
\hline & $\begin{array}{l}\text { Before } \\
\text { brushing }\end{array}$ & $\begin{array}{l}\text { Without } \\
\text { paste }\end{array}$ & $\begin{array}{l}\text { Paste }-50 \\
\text { Silica }\end{array}$ & $\begin{array}{l}\text { Paste-52 } \\
\text { alumina }\end{array}$ & $\begin{array}{l}\text { Paste-80 } \\
\text { Silica }\end{array}$ & $\begin{array}{l}\text { Paste-114 } \\
\text { Silica }+\mathrm{TiO}_{2}\end{array}$ & $\begin{array}{l}\text { MEAN } \\
\text { toothpaste }\end{array}$ \\
\hline Ceramic & $469.5(22.2)$ & $-7.2(10.8)$ & $-10.4(8.8)$ & $-12.1(4.4)$ & $-5.0(10.2)$ & $-7.1(10.4)$ & $-8.64(8.4)^{\mathrm{x}}$ \\
\hline $\mathrm{Co}-\mathrm{Cr}$ & $527.8(8.5)$ & $+5.1(5.1)$ & $+15.4(9.2)$ & $+15.4(9.6)$ & $+17.7(13.3)$ & $+18.6(13.8)$ & $+16.8(10.5)^{\mathrm{y}}$ \\
\hline $\mathrm{Ni}-\mathrm{Cr}$ & $312.7(41.8)$ & $+7.7(2.8)$ & $+26.9(27.3)$ & $+22.3(14.6)$ & $+22.2(20.7)$ & $+21.2(20.6)$ & $+23.2(9.1)^{\mathrm{y}}$ \\
\hline cpTi & $480.5(8.2)$ & $+0.2(3.1)$ & +18.5 (9.6) & $+4.8(3.6)$ & $+15.4(3.3)$ & $+20.1(12.5)$ & $+14.7(9.6)^{\mathrm{x}}$ \\
\hline Mean material & & $+1.32(8.2)^{\mathrm{a}}$ & $+12.6(2.3)^{\mathrm{a}}$ & $+7.6(3.1)^{\mathrm{a}}$ & $+12.6(2.1)^{\mathrm{a}}$ & $+13.2(1.3)^{\mathrm{a}}$ & \\
\hline
\end{tabular}

* Mean for 4 types of toothpaste. Different letters indicate statistical differences (two-way ANOVA, Tukey post-hoc test, $P<0.05$ )

hardness $(P<0.01)$, both before and after brushing. Whereas $\mathrm{Co}-\mathrm{Cr}$ and $\mathrm{Ni}-\mathrm{Cr}$ became slightly harder over brushing, the Vickers hardness values for ceramic and titanium decreased $(P<0.05)$. The type of toothpaste used did not affect these variations of microhardness.

Third-body wear appeared to be the abrasive wear pattern on the metal surfaces after brushing (Fig. 3). The morphology of the abrasive particles of the different toothpastes is characterized by a polyedric round form (Fig. 4). Particles of toothpaste with less abrasive capacity are smaller and more spherical than those with more abrasive capacity.

\section{Discussion}

The influence of the type of restorative material and toothpaste on brushing abrasion was evaluated in this in vitro study. Among the materials tested, $\mathrm{Co}-\mathrm{Cr}$ alloy exhibited the highest resistance to abrasion as measured by mass and by volume and the highest hardness value. A significant correlation between abrasion resistance and surface hardness has been observed in dental casting alloys [23] glass ionomers [14] and in resins [12]. Commercially pure titanium demonstrated the least resistance to abrasion, as has been observed in another study [24]. Although ceramic specimens exhibited higher resistance to abrasion according to weight loss, they showed the greatest amount of volume loss, due to their low density $\left(2.28 \mathrm{~g} / \mathrm{cm}^{3}\right)$ compared with cpTi $\left(4.51 \mathrm{~g} / \mathrm{cm}^{3}\right), \mathrm{Ni}-\mathrm{Cr}\left(8.05 \mathrm{~g} / \mathrm{cm}^{3}\right)$ and Co-Cr $\left(8.20 \mathrm{~g} / \mathrm{cm}^{3}\right)$.

Abrasion can have clinical consequences as a result of changes to the characteristics of the restorative material, as well as through the ingestion of the elements. The surface roughness did not vary significantly, so no higher plaque accumulation can be expected. However, the higher or
Fig. 3 SEM images of a Ni-Cr alloy surface before (a) and after (b) 420 minutes of brushing with Paste-114

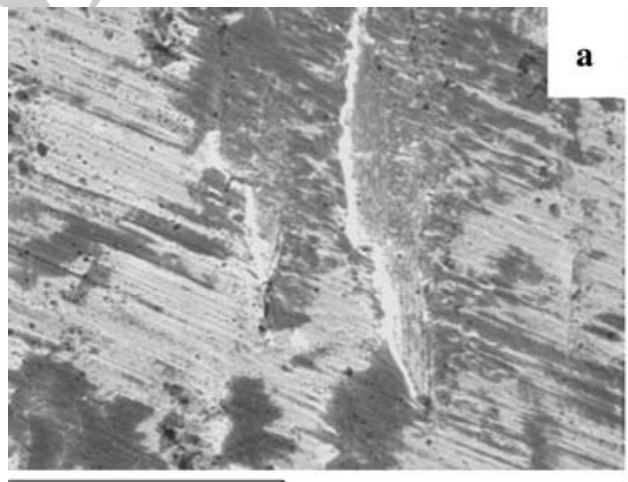

$90 \mu \mathrm{m}$

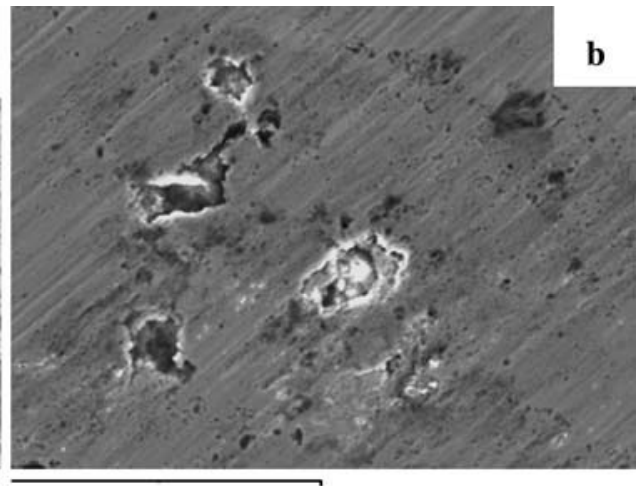

$60 \mu \mathrm{m}$ 
Fig. 4 ESEM micrograph of the abrasive particles of the four toothpastes: (a) Paste-50, (b) Paste-52, (c) Paste-80 and (d) Paste-114
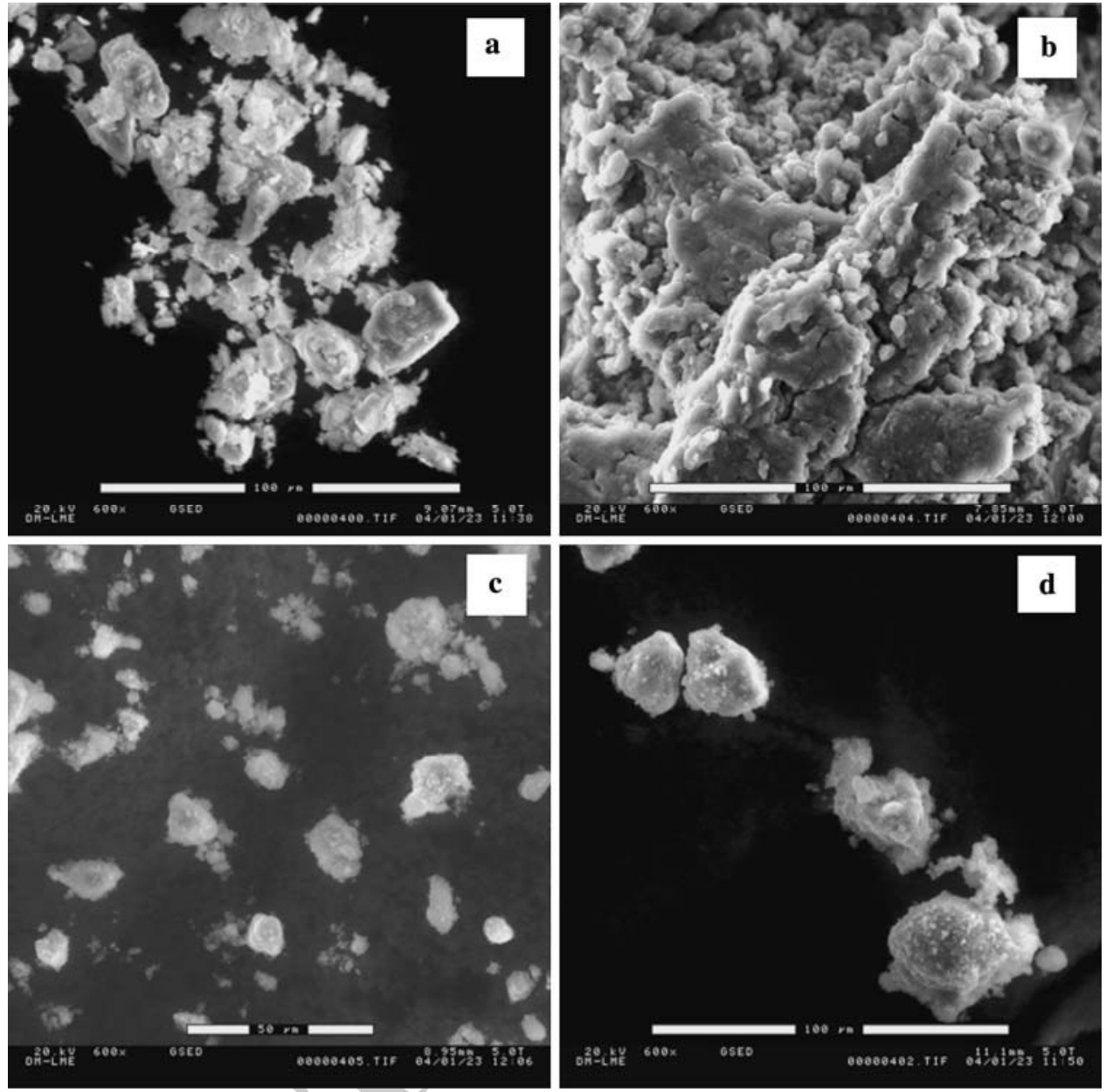

lower accumulation of dental plaque depends not only on the roughness of the surface. Some other factors, as the interfacial free energy of adhesion of bacteria and $\mathrm{pH}$ may also be involved [25]. Although the measurement of roughness did not reflect the entire surface, five different lengths for each material were analyzed. The abrasive particles from toothpaste present higher hardness values than the dental materials and produce plastic deformation up to fracture of the peaks of the surface profile. This lack of change in roughness despite the mass loss may be due to the mechanical polished produced by the abrasive particles. In contrast, a rougher surface was observed in composite material because of the selective abrasion of the resin matrix and the dislodgement of filler particles [9]. Moreover, the style of brush may wear the material evenly. Microhardness presents an increase due to the plastic deformation on the surface of the materials tested produced by the friction of the abrasive particles. Plastic deformation produced by abrasive mechanisms is well known that produces a high density of dislocations in the metallic surface, increasing the surface michohardness [26]. Wataha and coworkers [16] found that $600-800 \mu \mathrm{g}$ of $\mathrm{Ni}$ were released per $\mathrm{cm}^{2}$ of $\mathrm{Ni}-\mathrm{Cr}$ alloy after brushing with toothpaste for $48 \mathrm{~h}$, a similar value to the present study, taking into account that $65 \%$ of the $\mathrm{Ni}-\mathrm{Cr}$ alloy composition is $\mathrm{Ni}$, and that the rate of mass loss tended to decrease as a function of time. This means that the daily intake of nickel due to brushing could be about $1 \mu \mathrm{g}$ assuming that all the surfaces brushed are $\mathrm{Ni}-\mathrm{Cr}$ alloy. As the tolerable upper daily intake level of nickel is $1 \mathrm{mg}$, this represents no risk unless the patient is allergic to nickel [27]. There are concerns regarding the release of metal ions from the nickel-based alloys to surrounding tissues and their cytotoxicity to the tissue's normal function. Despite these concerns, results from the effect of Nickel-containing dental cast alloys in cell culture system are contradictory [19]. Moreover, $\mathrm{Ni}-\mathrm{Cr}$ showed a small increase in cytotoxicity after being brushed under several relativity severe in vitro conditions, such as at pH 4 [17]. Large areas of the biological interaction of dental casting alloys are not yet understood, especially in the area of low dose exposure and individual differences in the appearance of adverse reactions [19].

The amount of abrasion from brushing depends on the type of toothpaste used. In the present study a positive 
correlation was observed between the RDA of the toothpaste and abrasion levels as measured by weight or volume loss in all materials except for $\mathrm{Co}-\mathrm{Cr}$ alloys. The RDA value of the toothpaste could also be useful to estimate its relative abrasivity on ceramic, $\mathrm{Ni}-\mathrm{Cr}$ alloys and commercially pure titanium, but not on $\mathrm{Co}-\mathrm{Cr}$ alloys. In addition to the RDA, the type of abrasive may also influence abrasion characteristics, explaining the slight difference in abrasivity of Paste-50 and Paste-52 on ceramic and $\mathrm{Ni}-\mathrm{Cr}$ compared with cpTi and $\mathrm{Co}-\mathrm{Cr}$, despite their similar RDA values.

It is very difficult to compare the results of the present study with other in vitro studies because of differences in methodology and materials tested. This study was designed to evaluate the effect of toothpaste on the abrasion of different restorative materials by means of a powered toothbrush. For this study, a load of $250 \mathrm{~g}$ was chosen because this is within the range of the optimum force for plaque removal with a powered toothbrush [28, 29] and according to the powered toothbrush manufacture's instructions [30]. However, most studies have used a load of 250-600 g and horizontal backand-forth movements of the brush to simulate manual toothbrushing [6, 7, 9-13]. To our knowledge, this is the first study that uses a real powered toothbrush to study abrasivity, possibly simulating better a clinical situation than a brushing machine. Most studies have evaluated abrasivity as a vertical wear profile measured by means of profilometry [6-9, 11, 14] whereas only a few studies have determined abrasivity through weight loss $[10,12,13]$. However, when a force is applied to a toothbrush without displacement, the bristles might abrade the material unevenly, meaning a single vertical wear profile may not be representative of the area brushed. The daily recommended time for brushing with toothpaste is 2 min twice, meaning a given tooth surface might typically be in contact with the toothbrush for a maximum of $5 \mathrm{~s}$ twice daily [5]. Therefore one hour of brushing in this experiment may be equivalent to one year of life for a tooth surface.

It is very difficult to extrapolate the results of the present study to a clinical situation, as the oral cavity is subject to changes in $\mathrm{pH}$ and temperature, a continuous flow of saliva, microbiological activity, occlusal load, as well as many other factors. In spite of the limitations of the present study, brushing caused abrasion of dental casting alloys and ceramic and the intensity of which depended upon the restorative material and the RDA of the toothpaste [31-35]. However, brushing dental casting alloys using a powered toothbrush and applying a load of $250 \mathrm{~g}$ with toothpaste of RDA of about 50 , one need not expect significant consequences from the clinical point of view.

\section{Conclusions}

This study suggests that dental casting alloys and ceramic are susceptible to abrasion by brushing with an electric toothbrush. In general, the amount of mass loss is proportional to the RDA value of the toothpaste. The increase of the microhardness was due to the plastic deformation produced by the abrasion and surface roughness do not presents apparent increase by the inclusion of the abrasive particles on the material roughness. These variations will produce an important increase on the corrosion behavior and ion release, as can be observed in Part II, Consequently, the toothbrushed can have were clinically relevant.

Acknowledgements This study was supported in part by a grant of Fundació Josep Finestres (FBG 302982/2004). The authors are grateful to the technicians Narcís Ros, Francisco Sacristán, and Joan Mestres for producing the specimens and Robin Rycroft for language assistance. The authors also thank Dentaurum ${ }^{\circledR}$ and BraunOralB ${ }^{\circledR}$ for their contribution of investment and power toothbrushes respectively.

\section{References}

1. C. Deery, M. Heanue, S. Deacon, P.G. Robinson, A.D. Walmsley, H. Worthington, W. Shaw, A.M. Glenny, J. Dent. 32, 197-211 (2004)

2. N.C. Sharma, C.R. Goyal, J.G. Qaqish, M.A. Cugini, M.C. Thompson, P.R. Warren, J. Dent. 33, 11 (2005)

3. J.I. Hefferren, J. Dent. Res. 58, 1535-1543 (1979)

4. ISO 11609. Dentistry-toothpastes requirements, test methods and marking (International Organisation for Standardization, Geneva, 1995) pp. $1-10$

5. S. Hooper, N. West, M. Pickles, A. Joiner, R. Newcombe, M. Addy, J. Clin. Periodontol. 30, 802-808 (2003)

6. T. Attin, U. Koidl, W. Buchalla, H.G. Schaller, A.M. Kielbassa, E. Hellwig, Arch. Oral Biol. 42, 243-250 (1997)

7. M. De Menezes, C.P. Turssi, A.T. Hara At, D.C. Messias, M.C. Serra, Clin. Oral Invest. 8, 151-155 (2004)

8. N. West, M. Addy, J. Hughes, J. Oral Rehabil. 25, 885-895 (1998)

9. N. Tanoue, H. Matsumura, M. Atsuta, J. Prosthet. Dent. 84, 93-97 (2000)

10. R. Richmond, T.V. Macfarlane, J.F. Mccord, Dent. Mater. 20, 124-132 (2004)

11. C. Haselden, J.A. Hobkirk, G.J. Pearson, E.H. Davies, J. Oral Rehabil. 25, 335-339 (1998)

12. K. Kawai, Y. Iwami, S. Ebisu, J. Oral Rehabil. 25, 264-268 (1998)

13. N. Anil, S. Bolay, Int. J. Prosthodont. 15, 483-487 (2002)

14. Y. Momoi, K. Hirosaki, A. Kohno, J.F. Mccabe, Dent. Mater. 13, 82-88 (1997)

15. J.C. Wataha, P.E. Lockwood, K.B. Frazier, S.S. Khajotia, J. Prosthodont. 8, 245-251 (1999)

16. J.C. Wataha, P.E. Lockwood, D. Mettenburg, S. Bouillaguet, J. Biomed. Mater. Res. 65B, 180-185 (2003)

17. J.C. Wataha, P.E. Lockwood, M.Noda, S.K. Nelson, D.J. Mettenburg, J. Prosthet. Dent. 87, 94-98 (2002)

18. W. Geurtsen, Crit. Rev. Oral Biol. Med. 13, 71-84 (2002)

19. G. Schmalz, P. Garhammer, Dent. Mater. 18, 396-406 (2002)

20. R.W. Wassell, A.W. Walls, J.G. Steele, Brit. Dent. J. 192, 199-211 (2002)

21. J.C. Wataha, J. Prosthet. Dent. 87, 351-363 (2002)

22. R. Wang, A. Fenton, Quintessence Int. 27, 401-408 (1996)

23. I. Watanabe, C. Ohkubo, J.P. Ford, M. Atsuta, T. Okabe, Dent. Mater. 16, 420-425 (2000) 
24. C. Ohkubo, I. Watanabe, J.P. Ford, H. Nakajima, T. Hosoi, T. Okabe, Biomater. 21, 421-428 (2000)

25. J. Tagami, M. Toledano, C. Prati, (Adv. Adhesive Dent. Kuraray Co.Ltd. Dirimido, Italy, 1999) pp. 59-73

26. J. Pena, F.J. Gil, J.M. Guilemany, Acta. Materialia. 50(12), 31173126 (2002)

27. J.F. Lopez-Alias, J. Martinez-Gomis, J.M. Anglada, M. Peraire, Dent Mater (in press)

28. G.A. Van Der Weijden, M.F. Timmerman, P.A. Versteeg, M. Piscaer, U. Van Der Velden, J. Clin. Periodontol. 31, 620-624 (2004)

29. G.I. Mccracken, J. Janssen, M. Swan, N. Steen, M. De Jager, P.A. Heasman, J. Clin. Periodontol. 30, 409-413 (2003)
30. J.J. Hefferren, Adv. Dent. Res. 16, 16 (2002)

31. F.J. Gil, J.A. Planell, J. Biomed. Mater. Res-A. 48, 682-688 (1999)

32. F.J. Gil, J.M. Manero, J.A. Planell, J. Mater. Sci. 30, 2526-2530 (1995)

33. J.M. Guilemany, F.J. Gil, J. Mater. Sci. 26, 4626-4630 (1991)

34. J. Muntasell, J.L.L. Tamarit, E. Cesari, J.M. Guilemany, F.J. Gil, Mater. Res. Bull. 24, 445-452 (1989)

35. J. Muntasell, J.L.L. Tamarit, J.M. Guilemany, F.J. Gil, E. Cesari, Mater. Res. Bull. 23, 1585-1590 (1988) 